\title{
Metastatic Unresectable Basal Cell Carcinoma
}

National Cancer Institute

\section{Source}

National Cancer Institute. Metastatic Unresectable Basal Cell Carcinoma. NCI Thesaurus.

Code $C 156788$.

A basal cell carcinoma that has spread from its orig inal site of growth to another anatomic site and is not amenable to surgical resection. 